\title{
Women and Media: An Analysis of Role of Women Journalist in Indian Media
}

\author{
Trishu Sharma
}

\begin{abstract}
This research is conducted on five different Hindi news channels and five different Newspapers. The purpose of this research was to know the representation of women journalist in print and television media in the form of byline, anchor, reporter, voice-over artist and Piece to Camera. News being covered by women journalist is also being analyzed on source based also. Content analysis method is used to conduct this study. Journalists were also categorized on the basis of covering hard news and soft news also.
\end{abstract}

Keywords : Women Journalist, Representation of Women Journalist.

\section{INTRODUCTION}

At present era in Indian scenario Women journalist are very easy to find in different mediums of media. Not only in print media but also in Electronic media both in Radio and television women journalist are playing very important role. Media researchers cannot forget initial days of Doordarshan news where Indian audience watched female news readers. In various TV debates we watch many debates on representation of women in each and every section of society but there are very few studies which highlighted the role and the part of female/Women journalist in Indian media. The importance of this present study will become prominent when we will get the real picture of the representation of women in Indian mainstream media, especially on the basis of research data and this present study is an sincere effort to know this status.

We can find and watch women journalist for covering various issues like sports, politics, crime, fashion, entertainment etc. But when we look at the ratio and percentage of representation of female journalist in both print and television media so the real picture may be identified in this context.

\section{REVIEW OF LITERATURE}

Vaishali H.B. (2015), in this study the research focused on women's role as journalist with a sample size of 50 Journalists. Both Male and female media people were the part of sample, especially the sample represents the media people who had senior positions at various Kannada television channels. Qualitative analyses has been used in this study along with a structured interview.

Rama Jha (1992) in her book raises points related to women journalists and in this book she mentioned the concerns over gender discrimination in India. In this book writer particularly focused on the issues by few male media persons who made problems viewed by Women media person into the jokes.

Sharma K., Dr. Sanjeev, (2005), in this article he criticized the ways how Indian media both print and electronic are portraying women in the era of globalization.

Tomar, Ranu (2011), in this paper researcher tried to highlight poor representation of issues related to women. The Researcher in this study tried to explore the struggle for transformation and also put all efforts to find or explore to bridge gap between social identities of women and men.

Objectives

1. To know the Gender based representation of Journalists in Indian print \& television Media.

2. To know the representation of women Journalist on various technical terms like, Anchor, By-line, PTC and Voice Over.

\section{RESEARCH METHODOLOGY}

The data was collected from primary sources to fulfill the objectives. The Primary data was collected from selected five newspapers and News Channels. Content analysis methodology has been used along observation in this study. Major selective newspapers for this study are Times of India, Hindustan Times, The Indian Express, Dainik Jagran, Dainik Bhasker. Major Selective Television News Channels for this study are Aaj-Tak, India TV, News18, ABP News, NDTV India and ZEE News. All the data has been collected between January 2019 to March 2019.

\section{Data Interpretation}

Data interpretation has been done on the basis of the data collected and analysis of the data is as follows

\footnotetext{
Revised Manuscript Received on July 22, 2019.

Dr Trishu Sharma, Associate Professor, School of Journalism \& Mass Communication, AURO University, Surat, Gujarat, India.
} 
Table-1 News and Articles Written by Female Journalists

\begin{tabular}{|c|c|}
\hline Name of the Newspaper & $\begin{array}{c}\text { Percentage of Articles } \\
\text { Written by Female } \\
\text { Journalists }\end{array}$ \\
\hline Times of India & $\mathbf{1 7 \%}$ \\
\hline Hindustan Times & $\mathbf{2 1 \%}$ \\
\hline The Indian Express & $\mathbf{1 8 \%}$ \\
\hline Dainik Bhasker & $\mathbf{1 1 \%}$ \\
\hline Dainik Jagran & $\mathbf{1 0 \%}$ \\
\hline
\end{tabular}

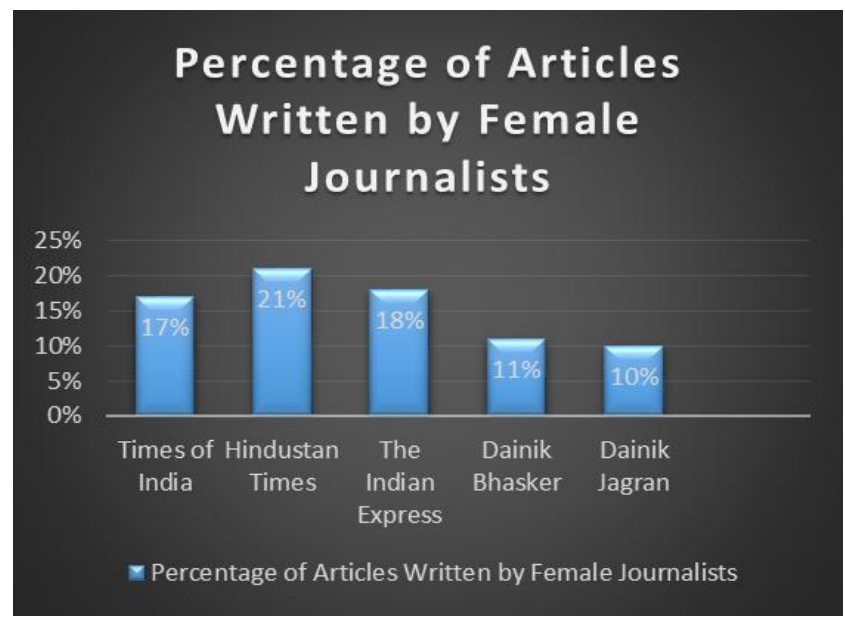

On the basis of above data and Table-1, it can be stated that maximum articles or news are written by female journalists are in Hindustan Times and minimum are with Dainik Jagran newspaper.

Table-2 News bulletins with Female Anchors during Prime Time

\begin{tabular}{|c|c|c|}
\hline $\begin{array}{c}\text { Name of the TV } \\
\text { News Channels }\end{array}$ & $\begin{array}{c}\text { Number of } \\
\text { Bulletins }\end{array}$ & $\begin{array}{c}\text { Percentage of } \\
\text { Bulletins with } \\
\text { Female Anchors }\end{array}$ \\
\hline Aaj-Tak & $\mathbf{9 0}$ & $\mathbf{3 8 \%}$ \\
\hline ABP News & $\mathbf{9 0}$ & $\mathbf{5 3 \%}$ \\
\hline NDTV India & $\mathbf{9 0}$ & $\mathbf{3 1 \%}$ \\
\hline India TV & $\mathbf{9 0}$ & $\mathbf{2 8 . 8 \%}$ \\
\hline News18 & $\mathbf{9 0}$ & $\mathbf{2 6 . 6 \%}$ \\
\hline
\end{tabular}

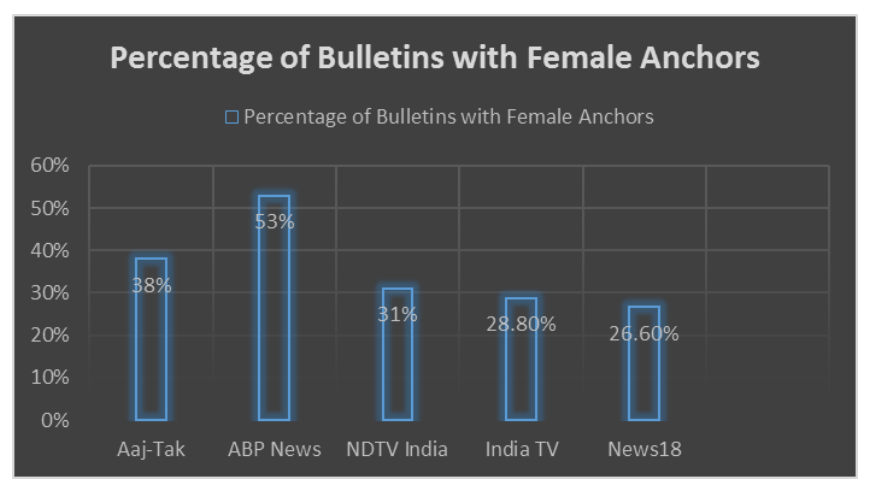

On the basis of above data and Table-2, it can be stated that in ABP News there are maximum female anchors and minimum female anchors are represented at News 18 .

Table-2 Female Journalists in PTC and Voice over at Television News

\begin{tabular}{|c|c|c|}
\hline $\begin{array}{c}\text { Name of the TV } \\
\text { News Channels }\end{array}$ & $\begin{array}{c}\text { Total } \\
\text { Stories }\end{array}$ & $\begin{array}{l}\text { Percentage of Female } \\
\text { Journalists in PTC } \\
\text { and Voice Over }\end{array}$ \\
\hline Aaj-Tak & $\mathbf{6 5 0}$ & $\mathbf{3 0 \%}$ \\
\hline ABP News & $\mathbf{6 9 5}$ & $\mathbf{2 7 \%}$ \\
\hline NDTV India & $\mathbf{7 3 4}$ & $\mathbf{2 7 . 6 \%}$ \\
\hline India TV & $\mathbf{7 2 3}$ & $\mathbf{2 8 . 2 1 \%}$ \\
\hline News18 & $\mathbf{7 9 5}$ & $\mathbf{2 8 . 0 5 \%}$ \\
\hline
\end{tabular}

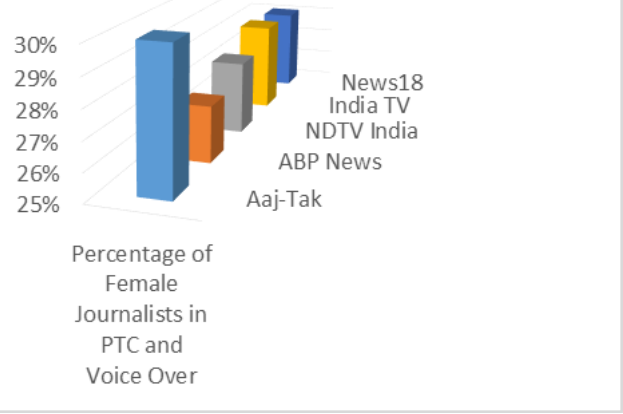

On the basis of above data and Table- 3 , it can be stated that maximum female journalists in PTC and Voice Over are represented in Aaj-Tak and minimum represented in ABP News.

\section{FINDINGS AND DISCUSSION}

Major Findings of this study are

1) It is proved that $80 \%$ of stories in print media are written and authored by male journalists and on an average only $20 \%$ articles are written and authored by Female Journalists.

2) In Print Media Maximum articles written by female journalists are in Hindustan Times and minimum article by female journalists are by Dainik jagran.

3) It is found and can be stated that, Yes there are more representation of Women journalists are there in television (only as Anchors).

4) $\mathrm{ABP}$ news has more Female anchors than all other selected news channels. ABP news has more than 50\% female news anchors.

5) News 18 has minimum Female news anchors in selected news channels.

6) Aaj-Tak represented women journalist maximum as far as PTC and Voice-over is concerned.

7) It is also found that there are less than $30 \%$ representation of women journalists in television news channels in PTC and Voice overs.

8) At ABP news there are minimum Women Journalists represented in PTC and Voice over.

Published By:

Blue Eyes Intelligence Engineering 


\section{CONCLUSION}

Discussions on women empowerment are very common at various mediums of media but representation of women journalists are need to be strengthen in Indian Print and electronic media. Bases on the data revealed in this study the representation of women journalists is very less. In various categories it is showed clearly. Women Journalists are also seen maximum in soft news category but it is also observed that women journalists are covering hard news like politics, crime and covering in conflict zones also.

\section{REFERENCES}

1. Kumar, K.J, (2002), Mass Communication in India, Jaico Publication.

2. Steiner, Linda, "Gender in the Newsroom", in Handbook of Journalism Studies, ed. Thomas Hanitzsch and Karin Wahl-Jorgensen (e-book, New York and London, 2009), p. 123, 126

3. Vaishali H.B 2015," Changing Face of Women Journalists in Leading Kannada Television Channels: A Study", International Journal of Scientific Research, Volume : 4, Issue : 8, Aug 2015, pp 663-665, ISSN No 2277 - 8179

4. Jha Rama (1992). Women and The Indian Print Media: Portrayal \& performance. Chanakya Publication.

5. Sharma K., Dr.Sanjeev, (2005), "Depiction of women in Indian media-A case of introspection for media planners" Samaj bigyan shodh Patrica, Amroha, Vol.1, no.1 April-Sept. pp.32-36.

6. Tomar, Ranu in her seminar paper (2011). "Gender and Media: Status of women journalist in Hindi Print Media in India" presented at University of Work, 19- '22 sept 